\title{
Overview of Approaches to Preventing and Avoiding Proteolysis During Expression and Purification of Proteins
}

\author{
Barry Ryan \\ Technological University Dublin, barry.ryan@tudublin.ie \\ Gary Henehan \\ Technological University Dublin, gary.henehan@tudublin.ie
}

Follow this and additional works at: https://arrow.tudublin.ie/ehsiart

Part of the Medicine and Health Sciences Commons

\section{Recommended Citation}

Ryan, B. and Henehan, G. (2013). Overview of approaches to preventing and avoiding proteolysis during expression and purification of proteins. Current Protocols in Protein Science, February. doi:10.1002/ 0471140864.ps0525s71

This Article is brought to you for free and open access by the ESHI Publications at ARROW@TU Dublin. It has been accepted for inclusion in Articles by an authorized administrator of ARROW@TU Dublin. For more information, please contact arrow.admin@tudublin.ie, aisling.coyne@tudublin.ie,gerard.connolly@tudublin.ie.

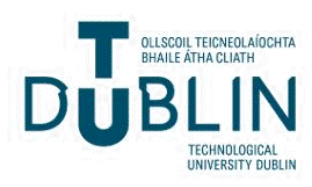




\title{
Overview of Approaches to Preventing and Avoiding Proteolysis During Expression and Purification of Proteins
}

\author{
Barry J. Ryan ${ }^{1}$ and Gary T. Henehan ${ }^{1}$ \\ ${ }^{1}$ Food Science and Environmental Health, Dublin Institute of Technology, Dublin, Ireland
}

\begin{abstract}
Proteases are enzymes that cleave proteins. They occur widely in nature and se fundamental role in cellular homeostasis; however, their presence can result in unwanted protein degradation during $\mathrm{r}$ binant protein expression and purification. This unit introduces proteases, specifically out g the types commonly encountered during production $\mathrm{ff}$ recombinant proteins. The strategies used to avoid and to prevent paplysis are also highli d with extensive consideration of the molecular, technical, and logi 1 methodologies involved. Curr. Protoc. Protein Sci. 71:5.25.1-5.25.7. (C) 2013 by John Wiley \& Sons, Inc.
\end{abstract}

Keywords: protease $\bullet$ proteolysis $\bullet$ recombinant protein

\section{INTRODUCTION}

Proteases are a class of enzymes that occupy a central position with respect to their physiological roles as well as their impact on biotechnology. The general reaction catalyzed by proteases is the degradation (or breakdown) of proteins. The importance of proteases is illustrated by the fact that they are found in all forms of living organisms. All cells maintain a rate of protein turnover by continuous degradation and synthesis of proteins. In addition, many cells produce extracellular proteases that break down large proteins into smaller proteins for absorption (see ?Rao et al., 1998? for review). All these protease activities have the potential to damage recombinant proteins during their expression. In this unit, the strategies used to avoid and prevent proteolysis during the expression of recombinant proteins are examined.

Proteases are members of the hydrolase family of enzymes (EC: 3.4). This enzyme family hydrolyzes peptide bonds with the participation of a water molecule. Proteases can be classified based on where this cleavage takes place. If the cleavage takes place within the polypeptide backbone, the protease is referred to as an endoprotease. Examples of endoproteases include trypsin and pepsin. Alternatively, if the cleavage takes place at the end of the polypeptide backbone, the protease is referred to as an exoprotease, with some common examples being aminopeptidases and car- boxypeptidases. Proteases have specific cleavage sites; for example, trypsin cleaves proteins at the carboxyl side of the amino acids lysine and arginine.

The most common recombinant host for protein production, E. coli, is known to possess both endo- and exoproteases distributed throughout the cell (Makrides, 1996; Huang et al., 2012). Mammalian cells contain compartmentalized endo- and exoproteases, which are vital for a number of cellular processes, including protein catabolism precursor activation (Steiner, 2011). Th 2 alytic mechanism is used to further characterize the protease family. Based on their key functional active-site residue(s), proteases are broadly characterized as shown in Table 5.25.1.

Proteolysis is a naturally occurring event within all cells and is necessary to maintain homeostasis (King et al., 1996). Proteases control cellular processes by removing denatured or misfolded proteins, thus eliminating a potentially dangerous buildup of unwanted protein material and simultaneously reducing the requirement for new cellular building blocks through catabolic "recycling." The La protease, a product of the lon gene, is responsible for hydrolysis of abnormal proteins in E. coli (Chung and Goldberg, 1981). Other roles for proteases include their involvement in apoptosis (Vandenabeele et al., 2005) and a possible role as "signaling scissors," wherein regulated intramembrane proteolysis controls signaling
Production of Recombinant Proteins

\subsection{1}

Supplement 71 
Table 5.25.1 Classification of Protease Families Based on Catalytic Active Site

\begin{tabular}{lll}
\hline Type & Active-site residues & Example \\
\hline Serine protease & Nucleophilic serine & Subtilisin (EC 3.4.21.62) \\
Cysteine protease & Nucleophilic cysteine & Papain (EC 3.4.22.2) \\
Aspartic protease & $\begin{array}{l}\text { Two highly conserved aspartate } \\
\text { residues }\end{array}$ & Plasmepsin (EC 3.4.23.39) \\
Metalloproteinase? & Catalysis involves a metal, often zinc & Adamalysin (EC 3.4.24.46) \\
\hline
\end{tabular}

in some receptors in the cell membrane (Buckingham, 2003).

In general, proteases are most effective in their native cellular surroundings 2 ere they are often compartmentalized into different subcellular environments. This physical separation reduces nonspecific or nonrequired protease action. Furthermore, protease activity is regulated within these environments (Vanaman and Bradshaw, 1999). However, to access proteins, either native or recombinantly expressed within the cellular environment, these cellular compartments must be disrupted or destroyed. Once these compartments are compromised, proteases can also access proteins from which they are normally physically separated. This is particularly important during protein purification. Careful consideration of the types of proteases present in the cell is required when attempting to reduce proteolysis during protein expression and subsequent purification.

\section{STRATEGIES FOR AVOIDING PROTEOLYSIS}

A number of strategies have been described to prevent proteolysis of prote poth native and recombinant, during their ssion. The majority of the examples described below refer to recombinant protein expression in $E$. coli, the most widely used host for protein expression (Samuelson, 2011). Other expression hosts are available, such as yeast strains, insect cells, and mammalian cells (Demain and Vaishnav, 2009). These other expression systems will have their own issues with protease activity, and similar strategies may be employed (see Martensen and Justesen, 2001). These will need to be approached on a caseby-case basis. A helpful review on protein expression system choices has been prepared by an international consortium of researchers (see Structural Genomics Consortium et al., 2008).

\section{Use of Protease-Deficient Cells}

Probably the simplest method to avoid proteolysis during expression is to use a commercially available protease-deficient host cell line. E. coli mutant cell lines that have been genetically engineered to reduce the effect of, or remove, native $E$. coli proteases are commercially available. For example, the E. coli strain BL21 (and its derivatives) is deficient in two proteases encoded by the lon (cytoplasmic protease) and ompT (periplasmic protease) genes. ?This strain is denoted by the phenotype $\Delta$ lon or $\Delta o m p T$, respectively.? The $\mathrm{K} 12 \mathrm{KS} 1000$ strain is lacking the Prc protease, which can degrade proteins expressed in the cytoplasm, while the K12 PR1031 strain is deficient in DnaJ, a chaperone that promotes protein degradation. The CAG597 and CAG629 strains are deficient in stress-induced proteases (see Ryan, 2011).

\section{Optimization of Expression}

Another simple but effective method to reduce protease activity is to manipulate the expression conditions to achieve a reduction in the level of misfolded heterologous proteing which often has the effect of avoiding pro ysis.

\section{Temperature}

One of the easiest parameters to alter is incubation temperature. Reduction in temperature results in the slower production of recombinant protein and can result in improved protein folding (Baneyx and Mujacic, 2004; Sörensen and Mortensen, 2005). Temperature is known to play a pivotal role in cellular processing; for example, some pances can function as chaperones (a "help rotein) at low temperatures, but act as proteases at elevated temperatures (Leidhold and Voos, 2007). Specialized vectors have been developed for expression of highly sensitive proteins at low temperatures (Mujacic et al., 1999).

\section{Preventing and Avoiding Proteolysis} 5.25 .2 


\section{Induction conditions}

The concentration of the inducing reagent [isopropyl- $\beta$-thio-galactoside (IPTG) in the case of commonly used lac operatorcontrolled expression] is another parameter that can be easily altered to achieve a decrease in production of misfolded proteins. With any optimization protocol, only one variable should be altered in any single experiment, and the effect of changing this parameter should be assessed over a feasible range on a small scale. For example, the effect of temperature on recombinant protein production may be examined by varying the incubation temperature from $20^{\circ} \mathrm{C}$ to $37^{\circ} \mathrm{C}$ in $\sim 5^{\circ} \mathrm{C}$ increments, using $10 \mathrm{ml}$ of culture broth. Once one variable has been optimized, keep that variable constant and repeat the optimization process with another variable, e.g., concentration of inducing reagent. The point at which inducer is added may also be significant. Thus, Galloway and co-workers (2003) have reported increased protein yield when the induction of protein expression was initiated in a late-logphase culture. ?Also, if induction time runs for several hours, then periodically checking protein expression during the induction phase may indicate a window for production of intact protein.?

\section{Use of Fusion Constructs}

Misfolded proteins may be targets for proteases if they do not form inclusion bodies (Baneyx and Mujacic, 2004). Fusion of the expressed protein of choice to a protective chaperone may offer significant benefit (Terpe, 2003). The oftentimes larger fusion protein can increase the solubility of the expressed protein of choice and can provide a "handle" for a single-step purification (Cheng and Lee, 2010). Examples of commonly used fusion proteins include maltose binding protein (MBP), N-utilizing substance A (NusA), and glutathione S-transferase (GST). These can all be produced by using commercially available vectors with specialized multiple cloning sites adjacent to the fusion gene to permit simple cloning and co-expression. One drawback to including a fusion protein in an expression and purification strategy is the requirement to remove the fusion protein from the protein of choice after purification. This, ironically, often takes the form of a proteolytic step employing a highly specific, and sometimes expensive, protease. This cleavage step should be completed as efficiently $P$ ssible and the protease removed by exhau dialysis.
Expressed Protein Targeting

Expressed proteins can be targeted to specific cellular compartments where they are less likely to encounter proteases. In E. coli, the typical example is targeting expression to the periplasmic space, which has fewer proteases than the cytoplasm. This is particularly effective for proteins that that require disulfide bonds for activity (Baneyx and Mujacic, 2004). The inclusion of a leader sequence $5^{\prime}$ to the gene of interest, such as the pelB leader, is used to direct translocation of the recombinant proteins to the periplasmic space (Barth et al., 2000). This strategy has resulted in many reports of successful translocation of expressed proteins (see Mergulhão et al., 2005 and references within). Because the periplasm contains fewer proteins than the cytoplasm, this strategy allows the protein of choice to be selectively released from the periplasmic envelope by gentle cell lysis (French et al., 1996). For some applications, the recombinant protein may be secreted into the culture medium. In this way, cell lysis is not required to harvest the protein of choice and the cellular proteases are not released (Ni and Chen, 2009). Proteins secreted into the culture supernatant can be collected effectively, as outlined by Caldwell and Lattemann (2004).

\section{Genetic Engineering of Gene Construct}

Proteases often cleave proteins at specific amino acid sequences. These residues can be identified by analyzing the gene of the recombinant protein for such cleavage sites. If deletion of these sites does not affect the functionality of the expressed protein, this strategy may be used to prevent proteolysis. As mentioned above in Use of Fusion Constructs, some purification protocols require the cleavage of a fusion protein; in these cases, the addition of specific protease recognition sites between the fusion protein and the protein of choice is required. Common examples of these types of recognition motifs include D-D-D-K for the enterokinase protease or E-N-L-Y-F-Q-G for the ?Tobacco Etch Virus? (TEV) protease.

A more radical approach is to randomly mutate the gene of interest to increase the stability of the protein $\square$ interest. One method of achieving this is ular permutation; this invorasion of the $\mathrm{N}$ - and C-terminal ends $\bigcirc$ the production of a new set of termini at a different location within the protein (Luger et al., 1989). Whitehead and coworkers (2009) have used this strategy to
Production of Recombinant Proteins

\subsection{5 .3}


reduce proteolytic cleavage and hence improve the half-life of a molecular chaperone from Methanocaldococcus jannaschii expressed in E. coli. However, with all such experiments care must be taken to retain protein functionality. Reduced proteolysis, although an important goal, cannot overshadow functionality of the recombinant protein of choice. If this is the case, an alternative strategy should be implemented to reduce proteolysis.

\section{STRATEGIES FOR PREVENTING PROTEOLYSIS}

In addition to avoiding proteolysis, it is possible to ment or minimize the action of proteases b $\bigcirc$ ng specific strategies. Some common strategies used for expression in $E$. coli are mentioned elsewhere (see Peti and Page, 2005). The same principles may be extended to other expression systems.

\section{How Do You Know Whether the Expressed Protein has Been Proteolyzed?}

It can sometimes be very difficult to determine whether poor expression is due to problems with inclusion body formation, expressed protein toxicity, culture conditions, or proteolysis during cell disruption. On occasion, it may be possible to observe electrophoretic microheterogeneity of an expressed protein band, but this is not always detectable. As a result, measures to reduce proteolysis may have to be taken in the absence of conclusive proof that this is an issue. This matter is further complicated when proteolysis is a consequence of misfolding due to rapid synthesis, i.e., only misfolded protein is hydrolyzed (see Vera et al., 2005). When proteolysis during expression is suspected, consider undertaking some of the more common initial measures outlined above. However, these strategies may not solve the proteolysis issue, and some further strategies aimed at minimizing proteolysis during cell disruption are outlined below. Of course, some of these may have drawbacks in terms of cost or time.

\section{Preventing Proteolysis During Cell Disruption}

As mentioned above, cell disruption is a critical period when proteases are liberated from membrane fragments and cellular compartments and begin acting on susceptible recombinant proteins. Cell disruption typically involves resuspending cells expressing a recombinant protein in a lysis buffer and break- ing the cells open using sonication, freezethaw cycles, and/or agents such as lysozyme or detergents (e.g., Triton X-100). It is critical that this cell lysis stage is carried out in a way that will minimize protein degradation, as described below.

When proteolysis is an issue during cell disruption, the following strategies may serve to limit proteolytic damage to expressed proteins:

\section{Keep everything cold}

Cell lysis and extraction are best carried out at low temperatures. Typically, an extraction buffer is ice cold and lysed cells are kept on ice until centrifugation. The low temperature slows the action of proteases.

\section{Work quickly}

For the most part, working quickly will serve to minimize proteolysis. The object is to purify the protein of interest as quickly as possible in order to minimize its contact with a protease. It is important to carry out cell disruption and subsequent chromatography on the same day. This avoids a situation in which the protease is in contact with the expressed protein for a prolonged period. Rapid purification is much easier at a laboratory scale than at a production scale.

\section{Addition of protease inhibitors}

A frequently used strategy is to add protease inhibitors to the extraction buffer to inhibit proteases liberated from subcellular compartments. Protease inhibitors are molecules that block the action of proteases either by covalent modification or by a specific interaction (Ryan, 2011). There are a number of commercially available protease inhibitors that may be added at the cell lysis stage either singly or as a cocktail. It is important that these are added as close to the time of cell breakage as possible, as many have short half-lives in solution (see below). Some of these inhibitors act by covalent modification of active-site residues of specific proteins. For example, phenylmethanesulfonyl fluoride (PMSF) reacts with an active-site serine in serine proteases. Some caution is needed in its use since it can modify the protein of interest if it has a susceptible serine residue. It is important to remember that PMSF is unstable in aqueous solution and needs to be added to cell lysis buffers immediately prior to use. Table 5.25.2 lists some examples of commonly used protease inhibitors. 
Table 5.25.2 Some Examples of Protease Inhibitors Used for the Four Main Classes of Protease $^{a}$

Inhibitor Concentr in lysis buffer Stock solution to prepare

Serine protease inhibitor

\begin{tabular}{|c|c|c|}
\hline $\mathrm{AEBSF}^{b}$ & $0.1-1.0 \mathrm{mM}$ & $\begin{array}{l}100 \mathrm{mM} \text { in water; store for } 1 \text { month at } \\
-20^{\circ} \mathrm{C}\end{array}$ \\
\hline PMSF & $0.1-1.0 \mathrm{mM}$ & $\begin{array}{l}200 \mathrm{mM} \text { in isopropanol, freshly prepared. } \\
\text { Add to lysis buffer immediately prior to use }\end{array}$ \\
\hline Leupeptin & $10-100 \mu \mathrm{M}$ & $\begin{array}{l}10 \mathrm{mM} \text { in water; store frozen for up to } 6 \\
\text { months }\end{array}$ \\
\hline
\end{tabular}

Cysteine protease inhibitor

$N$-ethylmale- $\quad$ Equimolar with protease to imide be inhibited

Antipain $\quad 1-100 \mu \mathrm{M}$

Aspartate protease inhibitor

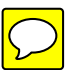

$10 \mathrm{mg} / \mathrm{ml}$ in water, freshly prepared

\begin{tabular}{|c|c|}
\hline Pepstatin & $1.0 \mu \mathrm{M}$ \\
\hline $\begin{array}{l}\alpha \text { 2-macro- } \\
\text { globulin }\end{array}$ & $\begin{array}{l}\text { Equimolar with protease to } \\
\text { be inhibited }\end{array}$ \\
\hline \multicolumn{2}{|c|}{ Metalloproteinase inhibitor } \\
\hline EDTA & $1-10 \mathrm{mM}$ \\
\hline
\end{tabular}

$1.0 \mathrm{mM}$ in methanol; store at $-20^{\circ} \mathrm{C}$

Prepare in water; store at $-20^{\circ} \mathrm{C}$

$100 \mathrm{mM}$ in water; store up to 1 year at $-20^{\circ} \mathrm{C}$

Bestatin $\quad 1-10 \mu \mathrm{M}$

$1.0 \mathrm{mM}$ in water; store up to 1 month at $-20^{\circ} \mathrm{C}$

${ }^{a}$ Further information can be found in Ryan (2011)

${ }^{b}$ ?4-(2-Aminoethyl)benzenesulfonylfluoride.?

Many of these inhibitors have limited specificity while others are specific for more than one class of protease. Trial experiments will be needed to establish which is appropriate for a given situation. A convenient starting point, when proteolysis is suspected, is to use one of the commercially available protease inhibitor cocktail mixes.

It is important to note that the list of inhibitors in Table 5.25.2 is far from exhaustive and that additional inhibitors are commercially available (Ryan, 2011). A database of proteases and their inhibitors has been established that can be a useful source of reference (Rawlings et al., 2012).

\section{Preventing Proteolysis of Proteins During Purification}

In general, proteolysis of proteins during purification of recombinant proteins is not a problem if steps have been taken to inactivate proteases at the cell lysis stage. On occasion, however, proteases may be carried over with a purified protein. This may be observed as gradual protein degradation during storage and

can be addressed by further purification or by re-application of specific protease inhibitors. The former is always preferable and a variety of chromatographic methods may need to be investigated (see Chapters 8 and 9).

It is important to be sure that loss of activity during purification is not due to causes other than proteolysis. There are a finite number of reasons for loss of activity or function of a protein during purification, ?and these are described below.?

\section{Oxidation}

Proteins that require a reduced thiol (on a cysteine residue, for example) for activity or function may become oxidized during purification. Thiols can be maintained in a reduced state by addition of $\beta$-mercaptoethanol or DTT (1 to $2 \mathrm{mM}$ ).

\section{Loss of cofactor or activating metal ion}

Some proteins require a cofactor or a metal ion for proper function. This can be lost during purification. Buffers containing EDTA (used for inhibition of metalloproteinases) are often
Production of Recombinant Proteins

5.25 .5 
a culprit since the EDTA can chelate metal ions. The solution is to exchange into a buffer lacking EDTA but containing the appropriate metal ion or cofactor.

\section{Inactivation by buffer components}

Some buffer salts may inactivate certain enzymes. The solution is to exchange into a different buffer.

\section{Inhibition by metal ions}

Certain divalent cations may interact with protein thiols to cause inactivation. EDTA is often added at a concentration of $2.0 \mathrm{mM}$ to prevent this inactivation.

All of these patterns of inactivation may be mistaken for proteolysis, thus causing inappropriate action to be taken. Therefore, it is essential to eliminate these causes before considering proteolysis in the absence of specific evidence (see Simpson, 2010 for a review of protein stability).

\section{SPECIAL PROBLEM OF EXPRESSION OF PROTEIN FRAGMENTS}

A particular problem may arise when an attempt is made to express a truncated protein or a particular domain of a protein that may not be an issue when expressing the full-length protein. According to some studies, this may be overcome by extending the ends by up to 20 amino acids (see Sörensen and Mortensen, 2005). This issue has been studied in detail by several groups, and systematic approaches to preventing proteolysis by terminal modifications have been reported (Bowie and Sauer, 1989; Structural Genomics Consortium et al., 2008).

\section{SUMMARY}

Proteolysis can occur at many stages during the production and purification of a recombinant protein. If protein degradation is suspected at any stage, it is crucial to examine the expression and purification protocols to ensure that true proteolysis has occurred. If proteolysis has been confirmed, alternative methods can be used during expression, cellular disruption, and purification to minimize protein degradation. It may be helpful to identify the type of protease involved in order to design a customized protocol to avoid proteolysis. However, investigation of the type of proteas $\rightarrow$ an empirical process and must be carried each individual protein. In all cases it is a better strategy to avoid proteolysis altogether than to have to prevent it after cell lysis and purification.

\section{LITERATURE CITED}

Baneyx, F. and Mujacic, M. 2004. Recombinant protein folding and misfolding in Escherichia coli. Nat. Biotechnol. 22:1399-1408.

Barth, S., Huhn, M., Matthey, B., Klimka, A., Galinski, E.A. and Engert, A. 2000. Compatiblesolute-supported periplasmic expression of functional recombinant proteins under stress conditions. Appl. Environ. Microbiol. 66:15721579.

Bowie, J.U. and Sauer, R.T. 1989. Identification of $\mathrm{C}$-terminal extensions that protect proteins from intracellular proteolysis. J. Biol. Chem. 264:7596-7602.

?Buckingham, S.D. 2003. RIPping and folding: Regulated intramembrane proteolysis. Signalling Scissors: New Perspectives on Proteases. Proceedings of the 3rd Horizon Symposium, Palazzo Argaza, I taly, October 23-25, 2003. http://www.nature.com/horizon/ proteases/background/ripping.html

Caldwell, R.B. and Lattemann, C.T. 2004. Simple and reliable method to precipitate proteins from bacterial culture supernatant. Appl. Environ. Microbiol. 70:610-612.

Cheng, C.-H. and Lee, W.C. 2010. Protein solubility and differential proteomic profiling of recombinant Escherichia coli overexpressing doubletagged fusion proteins. Microb. Cell Factories 9:63.

Chung, C.H. and Goldberg, A.L. 1981. The product of the lon $($ capR) gene in Escherichia coli is the ATP-dependent protease, protease La. Proc. Natl. Acad. Sci. U.S.A. 78:4931-4935.

Demain, A.L and Vaishnav, P. 2009. Production of recombinant proteins by microbes and higher organisms. Biotechnol. Adv. 27:297-306.

French, C., Keshavarz-Moore, E., and Ward, J.M. 1996. Development of a simple method for the recovery of recombinant proteins from the E. coli periplasm. Enzyme Microb. Technol. 19:332-338.

Galloway, C.A., Sowden, M.P., and Smith, H.C. 2003. Increasing the yield of soluble recombinant protein expressed in E. coli by induction during late log phase. Biotechniques 34:524530.

Huang, C.J., Lin, H., and Yang, X. 2012. Industrial production of recombinant therapeutics in Escherichia coli and its recent advancements. J. Industrial Microbiol. Biotechnol. 39:383-399.

King, R.W., Deshaies, R.J., Peters, J.M., and Kirschner, M.W. 1996. How proteolysis drives the cell cycle. Science 6:1652-1659.

Leidhold, C. and Voos, W. 2007. Chaperones and proteases-guardians of protein integrity in eukaryotic organelles. Ann. N.Y. Acad. Sci. 1113:72-86 
Luger, K., Hommel, U., Herold, M., Hofsteenge, J., and Kirschner, K. 1989. Correct folding of circularly permuted variants of a beta alpha barrel enzyme in vivo. Science 243:206-210.

Makrides, S.C. 1996. Strategies for achieving highlevel expression of genes in Escherichia coli. Microbiol. Rev. 60:512-538.

Martensen, P.M. and Justesen, J. 2001. Specific inhibitors prevent proteolytic degradation of recombinant proteins expressed in High Five cells. Biotechniques 30:782-788.

Mergulhão, F.J.M., Summers, D.K., and Monteiro, G.A. 2005. Recombinant protein secretion in Escherichia coli.Biotechnol. Adv. 23:177-202.

Mujacic, M., Cooper, K.W., and Baneyx, F. 1999. Cold-inducible cloning vectors for lowtemperature protein expression in Escherichia coli: Application to the production of a toxic and proteolytically sensitive fusion protein. Gene 238:325-332.

Ni, Y. and Chen, R. 2009. Extracellular recombinant protein production from Escherichia coli. Biotechnol. Lett. 31:1661-1670.

Peti, W. and Page, R. 2005. Strategies to maximize heterologous protein expression in Escherichia coli with minimal cost. Protein Exp. Purific. 51:1-10.

Rao, M.B., Tanksale, A.T., Ghatge, M.S., and Deshpande, V.V. 1998. Molecular and biotechnological aspects of microbial proteases. Microbiol. Mol. Biol. Rev. 62:597-635.

Ryan, B. 2011. Avoiding proteolysis during protein chromatography. Methods Mol. Biol. 681:61-71.

Rawlings, N.D., Barrett, A.J., and Bateman, A. 2012. MEROPS: The database of proteolytic enzymes, their substrates and inhibitors. Nucl. Acids Res. 40:D343-D350.

Samuelson, J.C. 2011. Recent developments in difficult protein expression: A guide to $E$. coli strains, promoters, and relevant host mutations. Methods Mol. Biol. 705:195-209.

Simpson, R. 2010. Stabilization of proteins for storage. Cold Spring Harb. Protoc. 2010: pdb.top79.

Sorensen, H.P and Mortensen, K.K. 2005. Soluble expression of recombinant proteins in the cytoplasm of Escherichia coli. Microb. Cell Factories $4: 1$.
Steiner, D.F. 2010. On the discovery of precursor processing. Methods Mol. Biol. 768:3-11.

Structural Genomics Consortium; China Structural Genomics Consortium; Northeast Structural Genomics Consortium, Gräslund, S., Nordlund, P., Weigelt, J., Hallberg, B.M., Bray, J., Gileadi, O., Knapp, S., Oppermann, U., Arrowsmith, C., Hui, R., Ming, J., dhe-Paganon, S., Park, H.W., Savchenko, A., Yee, A., Edwards, A., Vincentelli, R., Cambillau, C., Kim, R., Kim, S.H., Rao, Z., Shi, Y., Terwilliger, T.C., Kim, C.Y., Hung, L.W., Waldo, G.S., Peleg, Y., Albeck, S., Unger, T., Dym, O., Prilusky, J., Sussman, J.L., Stevens, R.C., Lesley, S.A., Wilson, I.A., Joachimiak, A., Collart, F., Dementieva, I., Donnelly, M.I., Eschenfeldt, W.H., Kim, Y., Stols, L., Wu, R., Zhou, M., Burley, S.K., Emtage, J.S., Sauder, J.M., Thompson, D., Bain, K., Luz, J., Gheyi, T., Zhang, F., Atwell, S., Almo, S.C., Bonanno, J.B., Fiser, A., Swaminathan, S., Studier, F.W., Chance, M.R., Sali, A., Acton, T.B., Xiao, R., Zhao, L., Ma, L.C., Hunt, J.F., Tong, L., Cunningham, K., Inouye, M., Anderson, S., Janjua, H., Shastry, R., Ho, C.K., Wang, D., Wang, H., Jiang, M., Montelione, G.T., Stuart, D.I., Owens, R.J., Daenke, S., Schütz, A., Heinemann, U., Yokoyama, S., Büssow, K., and Gunsalus, K.C. 2008. Protein production and purification. Nat. Methods 5:135-146.

Terpe, K. 2003. Overview of tag protein fusions: from molecular and biochemical fundamentals to commercial systems. Appl. Microbiol. Biotechnol. 60:523-533.

Vanaman, T.C. and Bradshaw, R.A. 1999. Proteases in cellular regulation. J. Biol. Chem. 274:20047.

Vandenabeele, P., Orrenius, S., and Zhivotovsky, B. 2005. Serine proteases and calpains fulfill important supporting roles in the apoptotic tragedy of the cellular opera. Cell Death Different. 12:1219-1224.

Vera, A., Arís, A., Carrió, M., González-Montalbán, N., and Villaverde, A. 2005. Lon and ClpP proteases participate in the physiological disintegration of bacterial inclusion bodies. J. Biotechnol. 119:163-171.

Whitehead, T.A., Bergeron, L.M., and Clark, D.S. 2009. Tying up the loose ends: Circular permutation decreases the proteolytic susceptibility of recombinant proteins. Protein Eng. Design Select. 22:607-613.
Production of

Recombinant

Proteins

5.25 .7 